\title{
ASSESSMENT OF PRODUCTION SYSTEMS OF CAMEL POPULATIONS UNDER PASTORAL MANAGEMENT IN SOUTHERN OROMIA, ETHIOPIA
}

\author{
Berhanu Bekele \\ School of Animal and Range Science, \\ Hawassa University, Hawassa, Ethiopia
}

\begin{abstract}
The major objective of the study was assessing production systems of camel populations in Southern Oromia. A total of 240 (120 from Borena and Guji Zone) households were selected randomly for interview. As majority of the respondents noticed that, the camel populations showed an increasing trend from time to time. Likewise most of the respondents replied that overall goat population was indicating increasing trend in lowland areas of the country. This is because; the small ruminants are easily managed unlike cattle; and also they adapt lowland environment. it is anticipated that the population of camel will increase in the near future. All pastoralists in this study respond that as they like increasing the number of camel heads in their herd for future in order to manage the futures food security. The reason for the wishes of the pastoralists in increasing the camels' number in the herd is that; they are physiologically and physically surviving animals of arid and semi-arid areas of the country and abroad. The major purpose of keeping camels across the study area was primarily to be used as a multi-purpose according to response of the pastoralists. Camels were good for a numbers of traits for those were the part of this study; like heat tolerance, tolerance to feed shortage and resistance to internal parasites than other livestock species in marginal areas. Thus care should be given to exploit the productive traits of camels to contribute on current demand for camel and camel by-products.
\end{abstract}

Keywords: Adaptation, Camels, Pastoralists, Production systems

\section{INTRODUCTION}

The camel plays a great role in food security of marginal areas society in arid and semi-arid. They live in wide arid and semiarid areas of the country, which are not suitable for crop production and also other livestock production. Therefore, in lowland parts of the country, the camels are considered as superior to all other livestock in terms of food security through the use of their products like milk and milk products, and also meat either direct use or income from a sale. Now a day, land degradation and rapid human population growth is occurring highly; that is why the camel's importance is going to increase; especially following the land degradation [1].

Although the camels play considerable role towards food security of society in semi arid and arid areas unlike other domestic animals, studies on their production systems is insufficient [2,3].

Therefore; this study was conducted to overcome such challenges with the objective; to assess the production system of the camels under pastoral management system.

\section{MATERIALS AND METHODS}

\section{A. Description of study area}

This study was done in Southern Oromia regional state of Ethiopia. Majority of this part of the country is consisted of pastoralists with dominantly existence of cattle, camel populations and goats and also some agro-pastoralists with cultivation behaviors. 


\section{B. Sampling technique and data collection}

Data were collected through the designed semistructured questionnaires from 240 (120 from Borena and 120 from Guji Zone) randomly selected households those have camels and experiences of rearing camels.

The secondary and primary data were collected from different sources to enrich this study with available informations. In this study, randomly selected pastoralists those have the camel and experience of camel rearing were briefed about feasibility and objective of the study before the starting of the actual data collection to encourage them in forwarding accurate information as much as possible.

C. Data Management and Analysis

After completing the data collection, they were handled in a fashion of mistakes reduction and corrected during the study period following the check up using pre-test. The data was analyzed using $[4,5]$.

\section{RESULTS AND DISCUSSION}

\section{A. Production systems}

In Ethiopian lowlands, the majority of the people are pastoralists and some of them are agro-pastoralists with a little cultivation practice and hunting and gathering could be their trend especially at long past. When looking for the system classification for animal production systems: there are different classes like; pastoral, agro-pastoral, extensive and intensive systems of livestock production. At the highland areas of the country, highest proportion of the human beings belongs to mixed farming. In the lowlands, however, livestock rearing is predominates, and there is little or no crop farming there. This report agreed with the study conducted by [6] who stated that as the majority of people on lowland area of the country as well as abroad are pastoralists and agro-pastoralists.

Pastoral production system in broad sense could be considered as life style which is entity based primarily on livestock production by using the scarce range resource for generating the income as well for attaining the home consumptions demand. There is also seasonal movement of herds in synchrony to the rainfall and range accessible regime, in order to access their herds with the feed to get at least the livestock products for their home consumption and this could be done by splitting their herds based on their production level, age structure, sex and health status again considered before displacing them to other areas in search of feed and water $[6,7]$.

\section{B. Trends of livestock}

In the study area, the pastoralists gave the response as the camel populations have been showed an increasing trend from time to time. Likewise majority of the respondents replied that overall goat populations showed increasing trend. This is because, the small ruminants are easily managed and they are less competing for feed unlike cattle.

As looked through interviewees and the group discussion highly noted that pastoralists and agropastoralists interested in increasing the number of camels in their herd for future to overcome the challenges might be occurred following the dramatic climatic change in the study areas and also they informed that this is again as to be the interest of the whole country and abroad at this time. Because the camels have an ability to adapt such a climatic change and survive with no water and available feed sources for a long time especially with no water they can spend unbelievable period of a time and also they tolerate the expansion of bush encroachment of arid and semi-arid areas. This agrees the work of $[8,6]$. they reported that changes in ecology, change in socio-cultural habits, and increased frequencies of drought, their importance by itself are giving an opportunity behind the expansion of camels into the Southern Oromia as well as the marginal areas of the country.

Pastoralists during group discussion indicated that camel were not reared by most pastoralists before 2 decades in Southern Oromia, however now a day the number of the camels at most of the pastoralists home accounted more like to that of the pastoral areas where camels existed before many years. This is an indicator of the pivotal role of the camels for the pastoralists either for home consumption or income generation where they were not known previously.

In contrast respondents reflected that cattle population showed a decreasing trend for about $67.5 \%$ pastoralists in Southern Oromia. This is in line with the study of [9] who reported that in Tocha, cattle populations were at decreasing trend for their number. Such decreasing trend might be associated with increasing in aridity of the area and changing climate that force pastoralists to have diversity of livestock species. In current study sites as reported in most of pastoral and agro-pastoral systems, camel is the best adapting animal because of its ability to adapt drought and shortage of water by their special 
physiological and physical features that they are gifted unlike the other domestic livestock.

Main income is generated from camel rather than other livestock may indicate the level of camels' importance in arid and semi-arid areas while comparing to other livestock species under the current rapid change of climate in a country. This is in agreement with earlier study [6] noted that increasing aridity shifted the type of mainly important livestock from cattle plus small stock to camels plus small stock almost in all pastoral areas of Southern Oromia and also pastoralists respond that as the social-cultural values of them increased based on the increment of camel number since the recent decades.

In determination of wealth among the Southern pastoral community the presence and absence of camel together with cattle are considered. This indicated that the pastoralists rearing camels were given high level of dignity.

\begin{tabular}{|c|c|c|c|c|c|c|}
\hline \multirow{4}{*}{ Species } & \multicolumn{6}{|c|}{$\begin{array}{l}\text { Table 1. Population trend of major livestock } \\
\text { species }\end{array}$} \\
\hline & & & & Sites & & \\
\hline & \multicolumn{2}{|c|}{ Borena } & \multicolumn{2}{|l|}{ Guji } & \multicolumn{2}{|c|}{ Overall } \\
\hline & $\begin{array}{l}\mathrm{N} \\
(120)\end{array}$ & $\%$ & $\begin{array}{ll} \\
(120)\end{array}$ & $\%$ & $\begin{array}{l}\mathrm{N} \\
(240)\end{array}$ & $\%$ \\
\hline \multicolumn{7}{|l|}{ Camel } \\
\hline Increasing & 117 & 97.5 & 118 & 98.3 & 235 & 97.9 \\
\hline Decreasing & - & - & - & - & - & - \\
\hline Stable & 3 & 2.5 & 2 & 1.7 & 5 & 2.1 \\
\hline \multicolumn{7}{|l|}{ Cattle } \\
\hline Increasing & 34 & 28.33 & 35 & 29.17 & 69 & 28.75 \\
\hline Decreasing & 82 & 68.33 & 80 & 66.67 & 162 & 67.5 \\
\hline Stable & 4 & 3.33 & 5 & 4.16 & 9 & 3.75 \\
\hline \multicolumn{7}{|l|}{ Goat } \\
\hline Increasing & 81 & 67.5 & 85 & 70.83 & 166 & 69.17 \\
\hline Decreasing & 31 & 25.83 & 30 & 25 & 61 & 25.42 \\
\hline Stable & 8 & 6.67 & 5 & 4.17 & 13 & 5.41 \\
\hline \multicolumn{7}{|c|}{$\mathrm{N}=$ Number of households } \\
\hline
\end{tabular}

\section{Aim of pastoralists for keeping camels}

The reasons for most of the pastoralists to keep camels were home consumption of the camel products, income generating through selling camels and their products, using for cultural functions and using them for different purposes with no specifying the purpose of camels (multi-purpose). Some pastoralists have no opportunity of selling camel milk for either they did not have lactating camels in their home or the shortage of milk that might not be quite enough to sale after attaining the home demand. This is in line with the study of [13], who noted that the Somali camel herders are interested towards the improvement of milk production and the continuous supply of milk and milk product for the home consumption throughout the year. There are also minor purposes of keeping camels like for drought power, breeding/mating, wealth status indicators and for security (pastoralists considered camels as a live banking system against the harsh conditions that might face and other naturally occurring events that hinder the feasibility of smaller stock more dangerously) [6].

Pastoralists involved in this study were not interested to sell the young female camels unless they are in serious or sudden events that may affect a future highly or they are highly in need of money for very critical issues. The studies of $[10,6]$ reported that, even though there might be expectation towards upcoming seasons which might be much worse, they still wish to keep the camel cows in order to make bright future with available food for themselves and to generate income.

Table 2. Camel keeping purpose

\begin{tabular}{|c|c|c|c|c|c|c|}
\hline \multirow[t]{2}{*}{ why } & \multicolumn{2}{|c|}{ Borena } & \multirow{2}{*}{$\begin{array}{l}\text { Guji } \\
\mathrm{N} \\
(120)\end{array}$} & \multirow[b]{2}{*}{$\%$} & \multicolumn{2}{|l|}{ Overall } \\
\hline & $\begin{array}{l}\mathrm{N} \\
(120)\end{array}$ & $\%$ & & & $\mathrm{~N}(240)$ & $\%$ \\
\hline $\begin{array}{l}\text { Home } \\
\text { consumption }\end{array}$ & 30 & 25 & 32 & 26.67 & 62 & 25.83 \\
\hline $\begin{array}{l}\text { Income } \\
\text { generating }\end{array}$ & 25 & 20.83 & 20 & 16.67 & 45 & 18.75 \\
\hline $\begin{array}{l}\text { Cultural } \\
\text { issues }\end{array}$ & 12 & 10 & 14 & 11.67 & 26 & 10.83 \\
\hline $\begin{array}{l}\text { Multi } \\
\text { purpose }\end{array}$ & 53 & 44.17 & 54 & 45 & 107 & 44.58 \\
\hline
\end{tabular}

\section{Milking frequency}

Most of the time pastoralists were milking their camels twice a day in the study area $(70.42 \%)$. Camel milk is the basic food for almost all the pastoralists of the country. Milk yield of camels at most of the pastoral areas of the country may range from 1-11 liters per day. This much variation of the yield is due to variation in feed availability, seasonal variation and unevenness of water access. 
Table 3. Milking frequency

\begin{tabular}{lllll}
\multicolumn{4}{c}{ Sites } & \\
\cline { 1 - 3 } Borena & \multicolumn{2}{c}{ Guji } & $\begin{array}{l}\text { Over } \\
\text { all }\end{array}$ \\
\cline { 1 - 4 } $\mathrm{N}$ & $\%$ & $\mathrm{~N}$ & $\%$ & $\mathrm{~N}$ \\
7 & 5.83 & 10 & 8.33 & 17 \\
89 & 74.17 & 80 & 66.67 & 169 \\
24 & 20 & 30 & 25 & 54
\end{tabular}

$\mathrm{N}=$ Number of households

\section{E. Preference of color}

Preference of pastoralists for different coat colors is associated with social and cultural trends and market demand. There was a little variation in preference of color for pastoralists of both selected zones. Borena pastoralists more preferred whitish coat color; whereas pastoralists of Guji preferred dark brownish coat colored camels. Likewise the study conducted by [1] noted that about $47.92 \%$ pastoralists in Yabello were more preferred whitish coat colored camels followed by dark brown for about $31.25 \%$ pastoralists of Yabello, whereas for $42.71 \%$ of respondents in Melka Soda, golden coat colored camels were more preferable followed by whitish (for $37.50 \%$ pastoralists in the same site). And also this is congruent with the study of [11] who reported as $29.30 \%$ of Ayro breeds were brown coat color.

\begin{tabular}{|c|c|c|c|c|c|c|}
\hline & \multicolumn{6}{|c|}{$\begin{array}{l}\text { Table } 4 \text { coat color preference of camels in the } \\
\text { study area }\end{array}$} \\
\hline & \multicolumn{6}{|c|}{ Sites } \\
\hline & \multicolumn{2}{|c|}{ Borena } & \multicolumn{2}{|c|}{ Guji } & \multicolumn{2}{|c|}{ Overall } \\
\hline & $\begin{array}{l}\mathrm{N} \\
(120)\end{array}$ & $\%$ & $\begin{array}{l}\mathrm{N} \\
(120)\end{array}$ & $\%$ & $\begin{array}{ll}\mathrm{N} \\
(240)\end{array}$ & $\%$ \\
\hline Colors & & & & & & \\
\hline $\begin{array}{l}\text { Dark } \\
\text { brown }\end{array}$ & 52 & $\begin{array}{l}43.3 \\
3\end{array}$ & 53 & 44.17 & 105 & 43.75 \\
\hline & 15 & 12.5 & 23 & 19.17 & 38 & 15.83 \\
\hline Whitish & 53 & $\begin{array}{l}44.1 \\
7\end{array}$ & 44 & 36.66 & 97 & 40.42 \\
\hline
\end{tabular}

$\mathrm{N}=$ Number of households.

\section{F. Level of adaptation}

Camel populations are very important animal in arid and semi-arid areas; because of their ability to survive or tolerate drought and shortage of water by their special features unlike the other livestock species. According to most of the respondents evolved in this study, camels were good for almost all adaptation traits as indicated in the table below. This is in line with the study conducted by [1] who reported that camels were good for their heat tolerance, feed shortage and tick tolerance in $\%$ Ethiopia. This is also congruent with the study 7.08 onducted by [12] who reported as the camels would 70.A2spond to hot arid areas by reducing urine 22.production, concentrating urine and economical sweating. Whereas this report in disagreement with the report of [1] for the tolerance to internal parasite who reported as the camels were moderate for tolerating the internal parasites in selected districts of Borena.

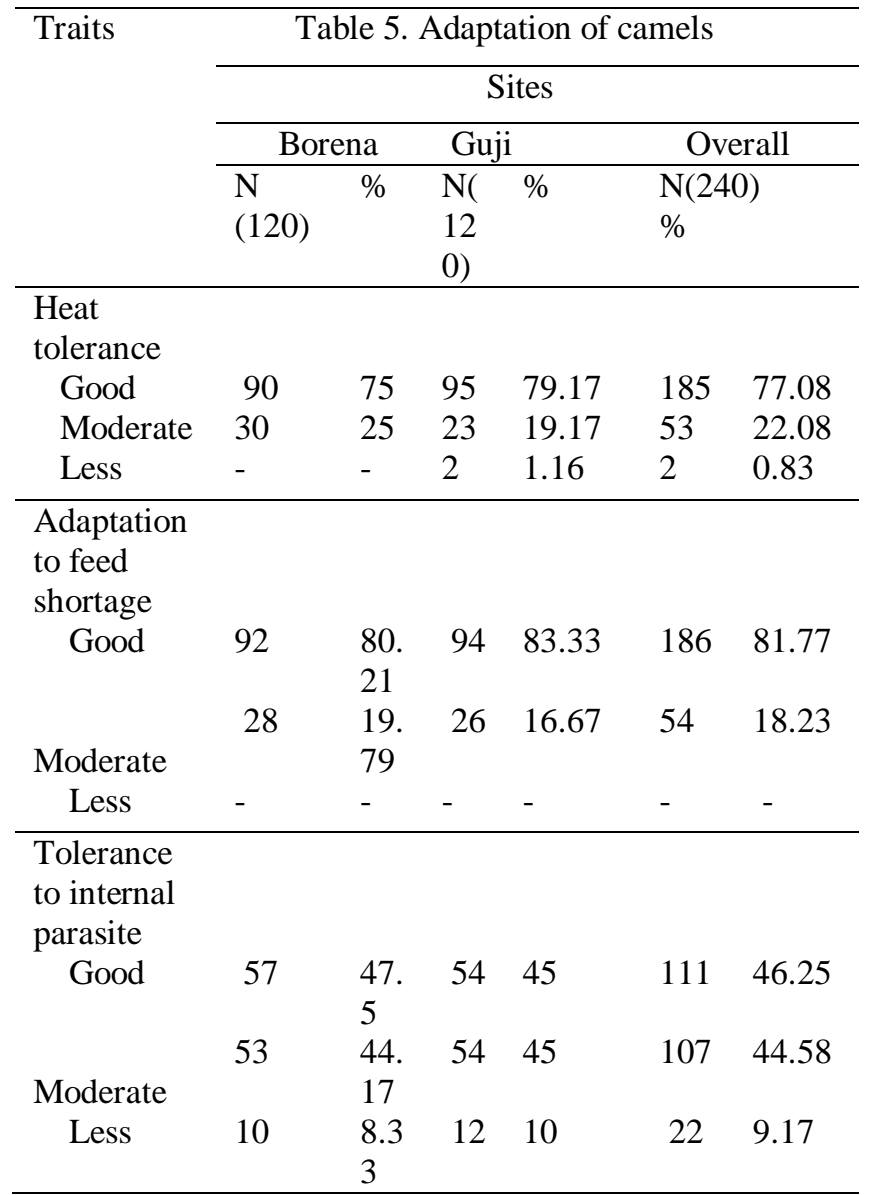

$\mathrm{N}=$ Number of households.

\section{CONCLUSION}

Assessing the production systems of the camel populations of the study area and country wise was very important issue when the study was conducted, so that the outcomes can give a direction to justify which livestock species should be kept for what purposes based on the demand of the society and also the level of adaptation of camels was focused and 
identified based on the pastoralists response and the reality on the ground. The consideration should be given for camel production performance to attain what as planned by creating awareness among pastoralists which contribute towards developing the sector.

\section{ACKNOWLEDGMENT}

I have a heart full thanks to the pastoralists who participated on this study.

\section{REFERENCES}

[1] Berhanu B. 2015. Phenotypic characterization of Camels and their production system in Yabello and Melka Soda

districts of Oromiya Region. M.Sc. Thesis submitted to Haramaya University, Ethiopia.

[2] Yohannes, M., Mekuriaw, Z. and Getachew, G. 2007. Camel and camel product marketing in

Babilie and Kebribeyah woredas of the Jijiga Zone, Somali Region, Ethiopia. Livestock Research for Rural

Development, 19:4.

[3] Yosef $T$, Kefelegn $\mathrm{K}$, Mohammed $\mathrm{Y}$, Mengistu U, Solomon A, Tadelle D, and J Han . 2014. Morphological

diversities and eco-geographical structuring of Ethiopian camel (Camelus dromedarius) populations. Journal of

Food Agriculture, 26 (4): 371-389.

[4] SPSS (2007). Statistical Package for Social Sciences SPSS for windows. User's guide: Statistics version 17. Inc. Cary, NC.

[5] SAS (Statistical Analysis System). 2008. Version 9.2, SAS Institute, United States of America.

[6] Berhanu B, Kefelegn K, Sisay $\mathrm{T}$ and Biressaw S. 2018. Phenotypic characterization of Camels and their production system in Oromiya Region. Ethiopian Journal of Agricultural Sciences 28(1): Pp33-49.

[7] Solomon, T. 2010. On-farm phenotypic characterizations of Boran cattle breed in Dire district of Borena Zone, Oromia Region, Ethiopia.

[8] Biffa, D. and Chaka, H. 2002. Camel and the changing system of Borena pastoral production.

Proceeding of the Annual Conference of the
Ethiopian Veterinary Association (EVA), pp. 72-87. Addis Ababa, Ethiopia.

[9] Amelmal A. 2011. Phenotypic characterization of indigenous sheep types of dawuro Zone and Konta special woreda of SNNPR, Ethiopia, M.Sc. Thesis submitted to Haramaya University, Ethiopia. [10] Getnet, A. 2004. Marketing information to select early warning indicators in Borena pastoral

production system.Volume II. pp. 87 - 95 . Proceedings of the 12th Annual Conference of the Ethiopian Society of Animal Production (ESAP) held in Addis Ababa, Ethiopia.

[11] Hassen, A., Muhyadin, M., Sisay, T. and Barre ,A. 2011. Phenotypic characterization of

Camels in Afder, Jijiga, and Shinile Zones of Somali Regional State, Ethiopia.

[12] Oujad, S., Kamel, B. 2009. Physiological particularities of Dromedary (Camelus dromedarius)

and experimental implications. Journal of Animal Science, 36:19-29.

[13] Farah KO, DM Nyariki , RK Ngugi, IM Noor , and AY Guliye . 2004. The Somaliand the Camel: Ecology, management and economics, 6(1):45. 